\title{
O DESENVOLVIMENTO NACIONAL SUSTENTÁVEL E AS LICITAÇÕES NO BRASIL
}

\author{
Cristina Mendes Bertoncini Corrêa ${ }^{1}$
}

\section{Resumo}

O presente artigo científico trata do desenvolvimento nacional sustentável e as licitações no Brasil. O seu objetivo principal é estudar o desenvolvimento sustentável e verificar como a Administração Pública brasileira está adotando esse critério nas suas contratações. Para tanto, utilizou-se a técnica de pesquisa bibliográfica, com método de abordagem dedutivo, que consiste na aplicação de regras na pesquisa jurídica para chegar-se a uma conclusão, partindo-se de premissas gerais - licitação pública e desenvolvimento sustentável - para verificar seus desdobramentos, ou seja, a sustentabilidade inserida na licitação pública. Para atingir este escopo, inicialmente, foi realizada uma análise histórica da Licitação no Brasil. Em seguida, foi realizada uma abordagem sobre o conceito de licitação e seus princípios setoriais. Após, foi trazido à baila o conceito de desenvolvimento sustentável, utilizando como subsídio o Relatório Brundtland, resultado da Comissão Mundial Sobre Meio Ambiente e Desenvolvimento. E finalmente, se pretendeu analisar as alterações sofridas pela Lei n. 8.666/93, trazidas pela Lei n. 12.349/10, que prescreveu uma nova redação ao artigo $3^{\circ}$ da Lei de Licitações e passou a prever a necessidade dos processos licitatórios cumprirem seu papel no desenvolvimento nacional sustentável. Porém, só a mudança na legislação não foi o suficiente para uma mudança no comportamento da Administração Pública, o que se pressupõe, se dará paulatinamente, com a inserção de medidas sustentáveis nos editais de licitação.

Palavras-chave: Licitação. Lei n. 8666/93. Desenvolvimento Sustentável.

\section{Introdução}

A licitação é um processo administrativo no qual se busca a proposta mais vantajosa para a Administração Pública contratar com terceiros. Esse conceito está em todos os doutrinadores do direito administrativo brasileiro. Porém, o conceito de vantajosidade que, anteriormente, era ligado quase que exclusivamente ao valor pecuniário da contratação pública passou a ter um novo significado com a inserção do desenvolvimento nacional sustentável nas Licitações Públicas. 
O presente artigo científico tem como objetivo principal estudar o desenvolvimento nacional sustentável e verificar como/e se a Administração Pública brasileira está adotando esse critério nas suas contratações.

Para atingir este objetivo, o artigo foi dividido em quatro seções. A primeira seção abordou as fases históricas da Licitação no Brasil. Assim, se verificou que as primeiras legislações sobre o assunto foram o Código de Contabilidade da União - Decreto n. 4536/22 e o Regulamento Geral de Contabilidade Pública - Decreto n. 15.783/22. Nesta fase, a Administração Pública tinha ampla discricionariedade e os decretos só atingiam a União Federal. Na segunda fase, o Decreto-lei n. 200/67 é o marco legal. Assim, ocorre o que se denominou de Unificação Nacional, ou seja, todos os entes federativos passaram a utilizar o Decreto n. 200/67 para as suas contratações públicas. A terceira fase tem como legislação fundamental a Lei n. 8.666/93 e se tentou demonstrar como essa norma acabou com a discricionariedade administrativa ao antecipar uma série de decisões acerca dos procedimentos licitatórios, o que acarretou que o edital e, consequentemente, a Administração, perdesse espaço e poder para regular as licitações. E finalmente, termina-se a seção com a análise da última fase a qual traz as diversas modificações ocorridas na Lei $n$. 8.666/93 demonstrando a necessidade da legislação licitatória se adequar às novas realidades da sociedade brasileira.

A segunda seção foi destinada ao estudo da Licitação, seu conceito e princípios norteadores. Neste sentido, estudou-se o conceito do procedimento licitatório e as suas finalidades, quais sejam, a busca da proposta mais vantajosa para a Administração Pública, a garantia do princípio da isonomia e por fim, o desenvolvimento nacional sustentável. Após, abordou-se os princípios setoriais da Licitação.

Já na terceira seção, passou-se a estudar o conceito de Desenvolvimento Sustentável. Aqui, a abordagem é multidisciplinar pois é trazido autores das mais diferentes áreas. Utilizou-se como conceito referencial o trazido no Relatório Brundtland, resultado da Comissão Mundial Sobre Meio Ambiente e Desenvolvimento. E assim, se tentou demonstrar que os métodos utilizados na economia das sociedades devem considerar as restrições impostas pelo meio ambiente e, nesse sentido, proteger a biodiversidade também é uma forma de promover o desenvolvimento da economia.

Na quarta e última seção, aborda-se a Sustentabilidade nas Licitações brasileiras. Para tanto, foi trazido todas as inserções normativas acerca do desenvolvimento sustentável nos procedimentos licitatórios, 
desde a Lei de Política Nacional sobre Mudanças Climáticas (Lei n. 12.187/ 09) até a Lei n. 12.349/10, que efetivamente modificou a redação do artigo $3^{\circ}$ da Lei n. 8.666/93. Porém, só a mudança na legislação não foi o suficiente para uma mudança no comportamento das Administrações Públicas. Foi preciso, ainda, a regulamentação através do Decreto n. 7.746/ 2012 e a Instrução Normativa MPOG n 01/10 para melhor se poder cumprir com a determinação legal. Mas mesmo assim, as "licitações verdes" ainda não são uma realidade na Administração Pública brasileira não ocorrendo nem em 1\% das compras realizadas pela Administração Pública federal, o que se pressupõe, que se dará paulatinamente, com a inserção de medidas sustentáveis nos editais de licitação.

Para tanto, utilizou-se a técnica de pesquisa bibliográfica, com método de abordagem dedutivo, partindo-se de premissas gerais - licitação pública e desenvolvimetno sustentável - para por fim, verificar seus desdobramentos, ou seja, a sustentabilidade inserida na licitação pública.

\section{As fases históricas da licitação no Brasil}

Para entender melhor como a licitação surgiu no Brasil, interessante adotar o ensinamento de André Rosilho (2013). Este autor divide o processo histórico da licitação no Brasil em quatro fases, quais sejam, "carta branca à Administração", "unificação nacional", "fetichismo legal" e finalmente "entre tensões e ajustes normativos".

A fase da "carta branca à Administração" tem como marco legal o Código de Contabilidade da União - Decreto n. 4.536/22 e o Regulamento Geral de Contabilidade Pública - Decreto n. 15.783/22. (ROSILHO, 2013, p. 36). Nesta fase, a Administração Pública tinha ampla discricionariedade na sua contratação e poucas eram as normas que ditavam as regras de como deveria ser feita a licitação.

Nas palavras do autor:

A regulação das contratações públicas, pelo simples fato de traçar balizas para a realização de compras governamentais, impunha, por óbvio, algum tipo de restrição à liberdade da Administração Pública para contratar. Entretanto, esta não era a tônica do modelo legal subjacente ao Regulamento Geral de Contabilidade Pública. [...] Optou-se por uma regulação branda, pouco invasiva, permitindo a Administração Pública decidisse ad hoc, como melhor licitar. (ROSILHO, 2013, p. 36) 
Algo característico dessa fase era o fato dos decretos se referirem à Administração Pública Federal e não ser utilizada a expressão "licitações públicas" mas sim "concorrências públicas".

Com a edição do Decreto-lei n. 200/67, que organiza a Administração Pública Federal, foram trazidas diversas regras relativas ao dever de licitar da Administração Federal. E logo a seguir, a lei n. 5.456/1968 determinou que os Estados e os Municípios deveriam aplicar as normas de licitações dos artigos 125 a 144 do Decreto-lei n. 200/67, nas suas contratações. E por isso, esta fase é chamada de "Unificação Nacional", pois todos os entes federativos da Administração Direta (União, Estados e Municípios) deveriam observar o princípio da licitação para suas compras, obras e serviços. (ROSILHO, 2013, p. 51)

A terceira fase do processo histórico da Licitação é chamada por André Rosilho (2013, p. 63) de "Fetichismo Legal". Este termo é trazido porque se acreditava, à época, que a forma de acabar com a corrupção existente no país seria colocar todas as regras de licitação na lei.

Conforme o referido autor:

Outra relevante consequência desta transformação [...] foi a redefinição do eixo da disciplina juriìdica das licitações, que passou a se centrar no combate à corrupção. Dessa forma, ganhou força a ideia de que seria possível, através de regras jurídicas precisas e bem dirigidas, conformar a ação dos agentes puìblicos e privados, evitando-se com isso práticas ilícitas e imorais nas contratações estatais. Tem início a cultura administrativa dos procedimentos em oposição a de resultados. (ROSILHO, 2013, p. 65)

Neste momento, o país estava se redemocratizando e a Constituição da República Federativa do Brasil de 1988 (CRFB/88) trouxe a obrigatoriedade da licitação no artigo 37, XXI, conforme disciplina:

ressalvados os casos especificados na legislação, as obras, serviços, compras e alienações serão contratados mediante processo de licitação pública que assegure igualdade de condições a todos os concorrentes, com cláusulas que estabeleçam obrigações de pagamento, mantidas as condições efetivas da proposta, nos termos da lei, a qual somente permitirá as exigências de qualificação técnica e econômica indispensáveis à garantia do cumprimento das obrigações. (BRASIL)

Para Carlos Pinto Coelho Motta (2005, p. 19) a promulgação da CRFB/ 88 apontava a necessidade de modernizar as normas de licitação vigen- 
tes. Afirma o autor, que, além de insuficientes, as normas anteriores revelavam as vicissitudes do sistema de aquisições e contratos.

Assim, apesar da Lei n. 8.666/1993 tomar como ponto de partida o Decreto-Lei n. 2.300/1986 (que apesar de ser uma norma editada no momento de redemocratização ainda tinha ranços ditatoriais), esta foi amplamente adaptada e modernizada, principalmente na matéria procedimental. Carlos Pinto Coelho Motta (2005, p. 19) reporta como sábia a atitude do legislador em conferir um caráter minucioso à Lei $\mathrm{n}$. 8.666/1993 - o que tornaria sua aplicação independente de regulamentação superveniente. O texto exaustivo levaria à unificação dos procedimentos.

Por outro lado, o diploma normativo foi tão detalhista ao antecipar para a lei, uma série de decisões acerca dos procedimentos licitatórios, que fez com que o edital e, consequentemente, a Administração, perdesse espaço e poder para regular as licitações.

Esta característica da Lei n. 8.666/93 de ser tão criteriosa e não permitir a discricionariedade do gestor público fez com que ocorresse uma cisão no Brasil, de um lado os juristas e os órgãos de controle defendendo o texto normativo e do outro, os gestores públicos vendo no mesmo a personificação do mal. (ROSILHO, 2013, p. 19). O autor explica:

Com a criação da Lei 8666/93 - lei nitidamente de ocasião, surgida em meio a uma série de escândalos de corrupção envolvendo contratações públicas -, os traços característicos da terceira fase das licitações ficaram ainda mais marcantes. Radicalizou-se a busca pela eliminação da discricionariedade da Administração para selecionar licitantes e reforçou-se a ideia de que as normas, se precisas, detalhistas, objetivas e bem-direcionadas, naturalmente gerariam boas contratações. Foram substancialmente ampliados o dever de licitar e o acesso ao setor empresarial ao mercado público. A Administração, com a edição desse diploma normativo, viu-se amarrada a uma complexa teia procedimental - que impactou significativamente a qualidade da gestão pública. (ROSILHO, 2013, p. 147)

Desta forma, em um país onde está se consolidando a democracia começou-se a verificar a necessidade de modificar esse quadro normativo, iniciando-se o que André Rosilho (2013, p. 144) denomina de quarta fase da licitação ("entre tensões e ajustes normativos") na qual se verifica a edição de novos textos normativos para tratar das contratações públicas bem como, a modificação de diversos artigos da própria Lei n. 8.666/93.

Esta fase é a atual, na qual tem-se a Lei n. 8.666/93 como o estatuto principal das Licitações Públicas no Brasil mas ao mesmo tempo tem-se 
a Lei n. 10.520/2002 (Lei do Pregão) e a Lei n. 12.462/2011 (Lei do Regime Diferenciado de Contratações Públicas - RDC) que trazem possibilidades de maior discricionariedade ao administrador público. Ademais, as inúmeras modificações legislativas na própria Lei n. 8.666/93 são características marcantes dessa nova fase. E a principal, para este artigo científico, é a modificação trazida pela Lei n. 12.349/2010 que inseriu no artigo $3^{\circ}$ da Lei n. 8666/93 o desenvolvimento nacional sustentável, in verbis:

A licitação destina-se a garantir a observância do princípio constitucional da isonomia, a seleção da proposta mais vantajosa para a administração e a promoção do desenvolvimento nacional sustentável e será processada e julgada em estrita conformidade com os princípios básicos da legalidade, da impessoalidade, da moralidade, da igualdade, da publicidade, da probidade administrativa, da vinculação ao instrumento convocatório, do julgamento objetivo e dos que Ihes são correlatos. (BRASIL)

As modificações trazidas pela Lei n. 12.349/2010 teve como escopo principal utilizar as licitações para incentivar o desenvolvimento nacional. Ou seja, a licitação não serve mais somente para suprir as necessidades da Administração Pública (compras, obras, serviços) mas também para fomentar o desenvolvimento nacional sustentável do país.

\section{Licitação e princípios setoriais}

O conceito de licitação é corrente no direito administrativo brasileiro. Licitação é o procedimento administrativo mediante o qual a Administração Pública seleciona a proposta mais vantajosa para o contrato de seu interesse. Ela propicia igual oportunidade a todos os interessados e atua como fator de eficiência e moralidade nos negócios administrativos.

Para Maria Sylvia Zanella Di Pietro (2011, p. 356), a licitação é o

Procedimento administrativo pelo qual um ente público, no exercício da função administrativa, abre a todos os interessados, que se sujeitem às condições fixadas no instrumento convocatório, a possibilidade de formularem propostas dentre as quais selecionará e aceitará a mais conveniente para a celebração do contrato.

Edmir Netto de Araújo (2014, p. 555), após trazer o conceito de licitação de quase todos os doutrinadores brasileiros, conceitua a licitação como um "processo administrativo, vinculado às normas legais específicas e ao instrumento convocatório, de que se serve a Administração para selecionar a proposta mais adequada e vantajosa para o interesse público $[\ldots] . "$ 
No mesmo sentido, Niebuhr (2012, p. 33-34):

a licitação pública é procedimento administrativo condicional à celebração de contrato administrativo mediante o qual a Administração Pública expõe a intenção de firmá-lo, esperando que, com isso terceiros se interessem e lhe ofereçam propostas, a fim de selecionar a mais vantajosa ao interesse público.

Assim, o processo licitatório deve, excetuados os casos específicos e constantes de Lei, anteceder os contratos celebrados entre a Administração Pública e um particular, ou seja, verificada a necessidade da Administração em adquirir determinado bem ou serviço, via de regra haverá a necessidade de realização de licitação objetivando contratar um particular capaz de fornecer tal bem ou serviço da forma mais vantajosa à Administração Pública.

Então é possível dizer que as três finalidades do procedimento licitatório são: a concretização do princípio da isonomia, assegurando aos administrados o ensejo de disputarem a participação nos negócios que a Administração Pública pretenda realizar com os particulares, a obtenção da proposta mais vantajosa, proporcionando às entidades governamentais, possibilidades de realizarem o negócio mais vantajoso e concorrer para a promoção do desenvolvimento nacional sustentável (JUSTEN FILHO, 2014, p. 497 a 499$)$.

Desta forma, no tocante à isonomia, a frase que melhor se adequa ao seu conteúdo é a trazida por Lúcia do Valle Figueiredo e Sérgio Ferraz (1994, p. 24) que explicam "a desigualdade não é repelida, o que se repele é a desigualdade injustificada". Isso significa que toda e qualquer discriminação deve constar do edital e a diferenciação só será válida se refletir a proposta mais vantajosa ou, atualmente, a proposta que corresponda à promoção de fins sustentáveis ou o desenvolvimento nacional.

O referido princípio pode parecer vulnerado quando deparado a uma situação fática de existência de duas propostas diferentes e a proposta mais onerosa, por possuir um determinado cunho de natureza sustentável, tenha sido a eventual escolha da Administração. Neste caso, a seleção realizada pelo administrador não estará fundada na arbitrariedade, mas sim, em preceito expresso na própria Lei - o desenvolvimento nacional sustentável. Assim, o poder de compra de um determinado ente da Administração Pública, nesta situação, é utilizado de forma estratégica, com uma escolha que o desenvolvimento nacional sustentável. 
Por isso a importância de se rever o conceito de vantajosidade da proposta, já que o mesmo sempre esteve muito ligado ao cunho econômico significando que a licitação deveria visar obter a solução contratual economicamente mais vantajosa para a Administração. A economicidade exigia que o Estado desembolsasse o mínimo e obtivesse o máximo. Porém, com a inserção de novas determinações legais, é necessária uma nova abordagem desta finalidade.

O Tribunal de Contas da União indo ao encontro do que foi dito acima, em sessão plenária, realizada em 2009, proferiu em seu Acórdão n. 1.978, o seguinte sobre a proposta mais vantajosa para a Administração:

8.1.1 o conceito da proposta mais vantajosa, inserido no caput do artigo $3^{\circ}$ da Lei n. 8.666/1993, não se confunde com o de 'mais barato', visto que sua compreensão pressuporia o atendimento das exigências constitucionais de economicidade e eficiência; 'as circunstâncias de uma determinada situação específica podem fazer com que o fornecimento por diversas empresas não seja útil para a Administração, sendo-Ihe manifestamente mais vantajoso que o objeto do contrato seja adjudicado a um único fornecedor'; em seguida, ampara o entendimento nos ensinamento de Antônio Carlos Cintra do Amaral, textualmente:

'É comum considerar-se que a maior vantagem para a Administração está sempre no menor preço. Isso reflete o entendimento, equivocado, de que a lei consagra a tese de que o mais barato é sempre o melhor, sem contemplação com a técnica e a qualidade. Esse entendimento não corresponde ao disposto na Lei 8.666/93 e conflita com os princípios da razoabilidade, eficiência e economicidade, que regem os atos administrativos, inclusive os procedimentos licitatórios.'

Para conseguir cumprir com suas finalidades, o procedimento licitatório é regido por vários princípios administrativos setoriais, quais sejam, o princípio da obrigatoriedade, o princípio da competitividade, o princípio da vinculação ao instrumento convocatório, o princípio do julgamento objetivo, entre tantos outros. Optou-se por trabalhar neste artigo somente com estes princípios setoriais porque os princípios gerais da Administração Pública ${ }^{2}$ pressupõe qualquer atuação administrativa, já sendo pré-requisito ao procedimento licitatório.

O primeiro princípio citado, o da obrigatoriedade, está consolidado no art. 37, XXI, da Constituição Federal que determina a obrigatoriedade da licitação para as compras, obras, serviços e alienações da Administração Pública brasileira. Este princípio admite as exceções de dispensa e inexigibilidade de licitação mas a regra é licitar. 
Já no tocante ao princípio da competitividade, José dos Santos CarvaIho Filho (2015, p. 252) explica que "a Administração não pode adotar medidas ou criar regras que comprometam, restrinjam ou frustrem o caráter competitivo da licitação". Mas o próprio autor (2015, p. 252/253) faz referência a inúmeras exceções previstas na própria Lei de Licitações como também na Lei Complementar n. 123/06 (Estatuto Nacional da Microempresa e Empresa de Pequeno Porte). Importante salientar que esta última Lei também tem como escopo o desenvolvimento nacional.

O princípio da vinculação ao instrumento convocatório é a chave mestra do processo licitatório. É o princípio que obriga a Administração Pública a respeitar estritamente as regras dispostas no instrumento convocatório (edital ou carta-convite) Este princípio está prescrito no artigo 41, caput, da Lei n. 8.666/93, que dispõe: "AAdministração não pode descumprir as normas e condições do edital, ao qual se acha estritamente vinculada". O descumprimento deste dispositivo, consequentemente, acarreta na nulidade do procedimento.

Já o último princípio setorial é o do julgamento objetivo, previsto tanto no artigo $3^{\circ}$ da Lei n. 8.666/93 quanto no artigo 45 da referida lei, respectivamente:

Art. 3. A licitação destina-se a garantir a observância do princípio constitucional da isonomia, a seleção da proposta mais vantajosa para a administração e a promoção do desenvolvimento nacional sustentável e será processada e julgada em estrita conformidade com os princípios básicos da legalidade, da impessoalidade, da moralidade, da igualdade, da publicidade, da probidade administrativa, da vinculação ao instrumento convocatório, do julgamento objetivo e dos que Ihes são correlatos.

Art. 45. O julgamento das propostas será objetivo, devendo a Comissão de licitação ou o responsável pelo convite realizá-lo em conformidade com os tipos de licitação, os critérios previamente estabelecidos no ato convocatório e de acordo com os fatores exclusivamente nele referidos, de maneira a possibilitar sua aferição pelos licitantes e pelos órgãos de controle.

Este princípio significa que "os critérios e fatores seletivos previstos no edital devem ser adotados inafastavelmente para o julgamento, evitando-se assim, qualquer surpresa para os participantes da competição." (CARVALHO FILHO, 2015, p. 251).

Após conceituar licitação e tratar, brevemente, dos princípios setoriais, necessário se faz conceituar o desenvolvimento sustentável. 


\section{O desenvolvimento sustentável}

O direito ao meio ambiente, enquadrado nos direitos de terceira geração, está hoje inserido de forma clara na Constituição da República Federativa do Brasil (CRFB/88):

225. Todos têm direito ao meio ambiente ecologicamente equilibrado, bem de uso comum do povo e essencial à sadia qualidade de vida, impondo-se ao Poder Público e à coletividade o dever de defendêlo e preservá-lo para as presentes e futuras gerações.

Quanto à evolução e surgimento do direito ambiental, José Afonso da Silva ensina:

A consciência ambientalista propiciou o surgimento e o desenvolvimento de uma legislação ambiental em todos os países, "variada, dispersa e frequentemente confusa" - consoante observa Ramón Martín Mateo, que acrescenta: "Em realidade, podemos detectar três tipos de normas: umas que constituem simples prolongamento ou adaptação das circunstâncias atuais da legislação sanitária ou higienista do século passado e da que, também em épocas anteriores, protegia a paisagem, a fauna e a flora; outras de cunho moderno e de base ecológica, ainda que de dimensão setorial, para o ar, a água, o ruído etc; e outras, por fim mais ambiciosas e que intentam interrelacionar os fatores em jogo, recolhendo numa normatividade única todas as regras relativas ao ambiente.

A essa normatividade jurídica do meio ambiente, lembrada por Martín Mateo, já se pode acrescentar um novo passo importante, qual seja, o de que Constituições mais recentes já incluem em seus textos normas sobre o tema [...]. (SILVA, 2011, p. 36).

O mesmo autor confirma que em relação ao Brasil "a tutela jurídica do meio ambiente, como é natural, sofreu profunda transformação" (SILVA, 2011 , p. 36). Isso porque, por um longo período de tempo não havia a consciência da proteção ambiental, levando a uma desproteção total. Nesse período o que sobressaía era a concepção do direito de propriedade o que por si só impunha ao Poder Público uma forte barreira à sua atuação como protetor do meio ambiente, ou seja, o direito a propriedade constituía-se como limitador da proteção ambiental. (SILVA, 2011, p. 3637).

Com o tempo, se passou a dar uma importância cada vez maior ao meio ambiente no Brasil, principalmente, com o evento internacional ocorrido no Rio de Janeiro, em 1992, conhecido como a Conferência da Rio 92 
(ECO 92). Porém, mesmo com a grande expectativa que o evento gerou ainda faltava muito para se efetivar a sustentabilidade no Brasil.

Hector Ricardo Leis (2014, p. 16) explica:

A Rio-92 gerou expectativas que não se realizaram sobre a possibilidade do sistema internacional desenvolver políticas efetivas a favor da sustentabilidade. É verdade que os paradigmas da modernidade ainda não esgotaram seu tempo histórico e continuam seduzindo os corações e mentes da maioria dos seres humanos, sejam pobres ou ricos. Mas interessa aqui destacar o fator contribuinte para isso, vindo da dinâmica principal do ambientalismo nas últimas décadas, consistente no esquecimento da descontinuidade entre os pressupostos das saídas ambientalmente sustentável para o planeta e os pressupostos da mentalidade que opera no mundo moderno.

Porém, antes ainda da Rio-92 já havia uma tendência mundial em se trabalhar com o termo sustentabilidade, ou desenvolvimento sustentável, ou ainda, ecodesenvolvimento. Assim, pode-se dizer que a expressão "desenvolvimento sustentável" teria surgido nas primeiras discussões relacionadas à preocupação com o futuro do planeta.

Segundo Guilherme Vieira Dias e José Glauco Tostes (p. 4):

O conceito de desenvolvimento sustentável, ou simplesmente DS, apareceu pela primeira vez em 1986 durante a Conferência Mundial sobre a Conservação e o Desenvolvimento promovida pela IUCN, em Ottawa, Canadá. Praticamente utilizado como sinônimo de ecodesenvolvimento, o desenvolvimento sustentável e equitativo deveria ter por princípio integrar conservação da natureza e desenvolvimento, de modo a satisfazer as necessidades humanas fundamentais mantendo a integridade ecológica e respeitando a diversidade cultural e a autodeterminação social.

E consolidou-se com o Relatório Brundtland, resultado da Comissão Mundial Sobre Meio Ambiente e Desenvolvimento (CMMAD), publicado em 1987. Esta comissão, presidida por Gro Harlem Brundtland (à época, primeira ministra da Noruega) teve como objetivo principal a pesquisa sobre os problemas ambientais no mundo (DIAS E TOSTES, p. 04).

O desenvolvimento sustentável é aquele que atende às necessidades do presente sem comprometer a possibilidade de as gerações futuras atenderem a suas próprias necessidades. Ele contém dois conceitos-chave: o conceito de 'necessidades', sobretudo as necessidades essenciais dos pobres do mundo, que devem receber a máxima prioridade; a noção das limitações que o estágio da tecnologia e da organização social impõe ao meio ambiente, impe- 
dindo-o de atender às necessidades presentes e futuras. Portanto, ao se definirem os objetivos do desenvolvimento econômico e social, é preciso levar em conta sua sustentabilidade em todos os países - desenvolvidos ou em desenvolvimento, com economia de mercado ou de planejamento central. Haverá muitas interpretações, mas todas elas terão características comuns e devem derivar de um consenso quanto ao conceito básico de desenvolvimento sustentável, e quanto a uma série de estratégias necessárias para sua consecução. (CMMAD, 1991, p. 46)

Desta forma, os métodos utilizados na economia das sociedades devem considerar as restrições impostas pela dimensão ambiental; portanto, proteger o meio ambiente também seria uma forma de promover o desenvolvimento da economia.

E aqui surge a crítica ao desenvolvimento sustentável pois muitos entendem que as palavras desenvolvimento e sustentabilidade são contraditórias. Isso porque, a sociedade é sustentável mas o desenvolvimento não. Ou seja, uma sociedade sustentável seria aquela que não usaria carros mas somente transportes públicos ou bicicletas, enquanto que o desenvolvimento sustentável seria a criação de carros menos poluentes (o que não resolveria o problema do meio ambiente mundial).

Pergunta-se, nesse momento, o que diferencia o desenvolvimento sustentável do desenvolvimento convencional. A conclusão mais plausível é que este último - leia-se as forças de mercado -, sob pressão da nova realidade ecológica e na necessidade de assumir uma nova postura, desponta sob uma nova roupagem, sem que tenha sido necessário modificar sua estrutura interna de funcionamento. O que, de fato, ocorreu. O mecanismo, cujo funcionamento é dependente da lógica do mercado, sequer foi abalado, ou melhor, saiu até mais fortalecido. (Layrargues, 1998, p. 152)

Porém, este não é o escopo do presente artigo. O que se pretendeu nesta seção foi trazer um conceito de desenvolvimento sustentável.

\section{O desenvolvimento sustentável e as licitações no Brasil}

Conforme já foi salientado anteriormente, a Lei n. 12.349/2010 trouxe diversas alterações na Lei n. 8.666/93, tendo como escopo principal utilizar as licitações para incentivar o desenvolvimento nacional sustentável. E por isso, Marçal Justen Filho (2012b, p. 62) explica que "o legislador pretendia era determinar que a contratação pública fosse concebida como um instrumento interventivo estatal para produzir resultados mais amplos 
do que o simples aprovisionamento de bens e serviços necessários à satisfação das necessidades estatais".

Nas palavras de André Luís Vieira (p. 23):

Em outras palavras, o consumo sustentável só se estabelece quando a cadeia produtiva é estimulada a produzir seus produtos de forma igualmente sustentável. Neste particular, a desoneração fiscal tributação ambientalmente orientada - juntamente com a contratação pública, igualmente, ambientalmente orientada pode instrumentalizar a mitigação dessa falha de mercado, fomentando os setores produtivos a oferecer a escalabilidade necessária de bens e serviços sustentáveis, tornando os preços ofertados atrativos para um patamar de consumo socialmente mais abrangente. Trata-se do alinhamento do papel do Estado, enquanto ente consumidor, agente econômico, ente regulador e, em última instância, elemento garantidor do bem-estar coletivo e do desenvolvimento social.

Porém, antes ainda da referida Lei, já existiam tentativas normativas de inserir nas licitações a preocupação com o meio ambiente, qual seja, a Lei n. 12.187/09, que foi a norma instituidora da Política Nacional sobre Mudanças Climáticas. Esta norma originou-se logo após a Conferência da ONU sobre Mudanças Climáticas de Copenhague, realizada em 2009, e que contou com a presença do Brasil. Esta conferência tinha como escopo o combate ao aquecimento global. Para atingir este propósito, exigiu-se maiores ações governamentais, como a promoção de licitações sustentáveis e gestão pública voltada aos aspectos sociais e ambientais.

No artigo $6^{\circ}$, XII, a referida Lei apresenta:

Art. 6o São instrumentos da Política Nacional sobre Mudança do Clima:

$[\ldots]$

XII - as medidas existentes, ou a serem criadas, que estimulem o desenvolvimento de processos e tecnologias, que contribuam para a redução de emissões e remoções de gases de efeito estufa, bem como para a adaptação, dentre as quais o estabelecimento de critérios de preferência nas licitações e concorrências públicas, compreendidas aí as parcerias público-privadas e a autorização, permissão, outorga e concessão para exploração de serviços públicos e recursos naturais, para as propostas que propiciem maior economia de energia, água e outros recursos naturais e redução da emissão de gases de efeito estufa e de resíduos. 
Assim, a lei sobre Política Nacional sobre Mudança do Clima impôs de forma expressa a adoção de critérios de sustentabilidade nas licitações, a fim de reduzir o impacto ambiental das ações do Poder Público. Porém, esta lei não acarretou modificações na Lei n. 8.666/93, no tocante à sustentabilidade nas licitações. E isso, com certeza, gerou a sua total inutilidade no tocante à utilização prática do desenvolvimento sustentável nas licitações.

Em 2010, a Presidente Dilma Roussef edita a Medida Provisória n. 495/2010, na qual propõe a modificação do artigo $3^{\circ}$ da Lei n. 8.666/93, com a inserção do termo Desenvolvimento Nacional. A Exposição de Motivos da medida provisória ressalta que:

Com referência às modificações propostas na Lei n. 8.666/93, é importante ressaltar que a mesma contempla diretrizes singulares para balizar os processos de licitação e contratação de bens e serviços no âmbito da Administração Pública. A norma consubstancia, portanto, dispositivos que visam conferir, sobretudo, lisura e economicidade às aquisições governamentais. Os procedimentos assim delineados são embasados em parâmetros de eficiência, eficácia e competitividade, em estrita consonância aos princípios fundamentais que regem a ação do setor público.

Paralelamente, impõe-se a necessidade de adoção de medidas que agreguem ao perfil de demanda do setor público diretrizes claras atinentes ao papel do Estado na promoção do desenvolvimento econômico e fortalecimento de cadeias produtivas de bens e serviços domésticos. Nesse contexto, torna-se particularmente relevante a atuação privilegiada do setor público com vistas à instituição de incentivos à pesquisa e à inovação que, reconhecidamente, consubstanciam poderoso efeito indutor ao desenvolvimento do país.

Percebe-se, facilmente, que a Medida Provisória não previa a sustentabilidade ambiental mas somente o desenvolvimento econômico do país. Isso foi bastante relevante.

A medida provisória 495/2010 ao ser convertida na Lei n. 12.349/2010 foi modificada no sentido de ser inserido o termo sustentável. Essa modificação foi substancial pois acrescentou uma nova finalidade à licitação, ao lado da busca da isonomia e da proposta mais vantajosa, conforme já demonstrado. Explica Marçal Justen Filho (2014a, p. 497) que agora a licitação tem uma função regulatória adicional, ou seja, não se busca mais somente a proposta mais vantajosa economicamente falando, mas também a oportunidade de fomentar o desenvolvimento sustentável. E assim arremata: 
A contratação administrativa passou a ser concebida como um instrumento para a realização de outros fins, além da promoção de compras, serviços e alienações. Por meio dos contratos administrativos, o Estado brasileiro intervém sobre diversos setores (econômicos, sociais, tecnológicos e etc...)

O desenvolvimento nacional sustentável significa o crescimento econômico norteado pela preservação do meio ambiente. Portanto, a licitação deve ser estruturada de modo a promover o crescimento econômico nacional em termos compatíveis com a proteção ao meio ambiente.

O grande problema é que apesar de ter havido a inserção do termo sustentável no caput do artigo $3^{\circ}$, não houve modificação alguma nos parágrafos do referido artigo. Ou seja, os critérios de preferências adotados na legislação mantiveram-se somente no tocante ao desenvolvimento nacional e não no desenvolvimento nacional sustentável. E isso provocou, inicialmente, um entendimento no Tribunal de Contas da União que poderia neutralizar a sustentabilidade. (JUSTEN FILHO, 2012b, p. 66)

E por isso, ensina Marçal Justen Filho, sobre as incoerências da decisão da Corte de Contas (2012b, p. 66):

[...] a primeira consiste em que as regras dos $\S \S 5^{\circ}$ a 12 do art. $3^{\circ}$ se destinam exclusivamente à promoção do desenvolvimento nacional - sem preocupações com outros aspectos do desenvolvimento sustentável. Trata-se de preferências oponíveis a produtos e serviços oriundos do estrangeiro ou que não satisfaçam requisitos atinentes à nacionalização dos produtos. Portanto, afirmar que as medidas de promoção do desenvolvimento nacional sustentável são apenas aquelas previstas no elenco do art. $3^{\circ}$ significa tornar irrelevante a proposta de proteção ao meio ambiente.

Em segundo lugar, não se afigura cabível subordinar a adoção de tratamento discriminatório à existência de previsão legal explícita e exaustiva. Nenhuma lei pode exaurir a disciplina das providências destinadas a dar concretude ao princípio da isonomia. Existe competência infralegal insuprimível nesse campo.

Assim, no sentido de regulamentar o disposto no artigo $3^{\circ}$ da Lei $n$. 8.666/93, foi publicado o Decreto Federal n. 7.746/2012 que estabelece formas de promoção ao desenvolvimento sustentável nas contratações, além de instituir a CISAP (Comissão Interministerial de Sustentabilidade na Administração Pública) e impor a elaboração e implementação de Plano de Gestão de Logística Sustentável pela Administração Pública Federal. Importante trazer à baila alguns artigos do decreto: 
Art. 2ำ A administração pública federal direta, autárquica e fundacional e as empresas estatais dependentes poderão adquirir bens e contratar serviços e obras considerando critérios e práticas de sustentabilidade objetivamente definidos no instrumento convocatório, conforme o disposto neste Decreto.

Parágrafo Único. A adoção de critérios e práticas de sustentabilidade deverá ser justificada nos autos e preservar o caráter competitivo do certame.

$[\cdots]$

Art. 4 São diretrizes de sustentabilidade, entre outras:

I - menor impacto sobre recursos naturais como flora, fauna, ar, solo e água;

II - preferência para materiais, tecnologias e matérias-primas de origem local;

III - maior eficiência na utilização de recursos naturais como água e energia;

IV - maior geração de empregos, preferencialmente com mão de obra local;

V - maior vida útil e menor custo de manutenção do bem e da obra;

VI - uso de inovações que reduzam a pressão sobre recursos naturais; e

VII - origem ambientalmente regular dos recursos naturais utilizados nos bens, serviços e obras.

Art. $5^{\circ} \mathrm{A}$ administração pública federal direta, autárquica e fundacional e as empresas estatais dependentes poderão exigir no instrumento convocatório para a aquisição de bens que estes sejam constituídos por material reciclado, atóxico ou biodegradável, entre outros critérios de sustentabilidade.

[...]

Art. 7ㅇ O instrumento convocatório poderá prever que o contratado adote práticas de sustentabilidade na execução dos serviços contratados e critérios de sustentabilidade no fornecimento dos bens.

Deste modo, o decreto trouxe para o edital de licitação os critérios de sustentabilidade e isso é fundamental para a efetividade da Lei n. 8.666/ 93 tendo em vista o já estudado princípio da vinculação ao instrumento convocatório. Ou seja, como esse princípio determina que a Administração deve estar vinculada ao que dispõe o edital, se determinado no edital, medidas de sustentabilidade, poderão ser exigidas na licitação tais medidas. 
Importante dizer, que na esfera federal, já se tinha a Instrução Normativa MPOG n. 01/10 que visava dispor sobre os critérios de sustentabilidade ambiental na aquisição de bens, contratação de serviços ou obras pela Administração Pública Federal direta, autárquica e fundacional.

E assim, alguns órgãos da Administração Pública começaram, principalmente a partir do ano de 2011, a utilizar os critérios de sustentabilidade nas suas contratações, conforme demonstra a Tabela 1 que traz os percentuais de compras com itens sustentáveis.

Tabela 1 - Compras com itens sustentáveis

\begin{tabular}{|l|l|l|}
\hline Ano & $\begin{array}{l}\text { Quantidade de } \\
\text { Processos de } \\
\text { compras }\end{array}$ & $\begin{array}{l}\text { Compras com itens } \\
\text { sustentáveis }\end{array}$ \\
\hline 2011 & 244.190 & $0,63 \%$ \\
\hline 2012 & 232.743 & $0,69 \%$ \\
\hline 2013 & 223.937 & $0,72 \%$ \\
\hline 2014 & 199.509 & $0,67 \%$ \\
\hline 2015 & 62.044 & $0,77 \%$ \\
\hline
\end{tabular}

Fonte: ComprasNet

Na tabela apresentada, mesmo não terminado o ano de 2015, já houve um percentual maior de compras pelo Governo Federal com itens sustentáveis do que nos anos anteriores. Porém, percebe-se que as compras ainda são bastante restritas.

O que efetivamente já está ocorrendo no país é a inserção das Micro e Pequenas Empresas nas contratações de compras da Administração Pública Federal conforme demonstra a Tabela 2 
Tabela 2 - Compras com participação de ME/EPP

\begin{tabular}{|l|l|l|}
\hline Ano & $\begin{array}{l}\text { Quantidade de } \\
\text { Processos de } \\
\text { compras }\end{array}$ & $\begin{array}{l}\text { Compras com } \\
\text { participação de } \\
\text { ME/EPP }\end{array}$ \\
\hline 2011 & 244.190 & $53,57 \%$ \\
\hline 2012 & 232.743 & $52,68 \%$ \\
\hline 2013 & 223.937 & $53,76 \%$ \\
\hline 2014 & 199.509 & $52,74 \%$ \\
\hline 2015 & 62.044 & $50,80 \%$ \\
\hline
\end{tabular}

Fonte: ComprasNet

Assim, pressupõe-se que paulatinamente as Administrações Públicas passarão a utilizar cada vez mais critérios de sustentabilidade nas suas contratações públicas. Porém, isso só ocorrerá se houver planos estratégicos de gestão neste sentido e uma política mais voltada ao desenvolvimento sustentável.

\section{Considerações finais}

Licitação é o procedimento administrativo mediante o qual a Administração Pública seleciona a proposta mais vantajosa para o contrato de seu interesse. Ela propicia igual oportunidade a todos os interessados e atua como fator de eficiência e moralidade nos negócios administrativos.

Considera-se que a licitação está presente na Legislação Brasileira desde o ano de 1922, e a partir daí, diversas normas regulamentaram tal instituto, até chegar à Lei n. 8.666/93.

Porém, em país onde está se consolidando a democracia começouse a verificar a necessidade de modificar esse o quadro normativo e inserir na legislação a preocupação com o meio ambiente saudável. 
O conceito de desenvolvimento sustentável foi objeto de estudo e discussão já na década de 80 sendo consolidado pelo Relatório Brundtland, em 1987. A preocupação com o meio ambiente e com as "gerações futuras" ficou explicitado, no Brasil, com a inserção, no texto constitucional, do artigo 225 da Constituição Federal que trouxe a incumbência à Administração Pública, da defesa e preservação do meio ambiente.

Assim, a possibilidade de inserção de critérios de sustentabilidade nos certames licitatórios vem sendo realizada ao longo dos anos e foi efetivamente colocada a partir da alteração sofrida na Lei n. 8.666/93 pela Lei n. 12.349/10, que modificou a redação do artigo $3^{\circ}$, inserindo como nova finalidade do procedimento licitatório, a promoção do desenvolvimento nacional sustentável.

Mas apesar de este fato poder ser considerado como um avanço importantíssimo para o benefício da sociedade, ainda havia resistência dos administradores públicos na inserção de critérios de sustentabilidade nos editais de licitação. Para resolver este problema, foi publicado o Decreto Federal n. 7.746/2012 que estabelece formas de promoção ao desenvolvimento sustentável nas contratações, além de instituir a CISAP (Comissão Interministerial de Sustentabilidade na Administração Pública) e impor a elaboração e implementação de Plano de Gestão de Logística Sustentável pela Administração Pública Federal.

Com esta regulamentação houve um aumento nas "licitações verdes", assim denominadas as licitações que utilizam critérios de sustentabilidade.

Mas mesmo assim, as "licitações verdes" ainda não são uma realidade na Administração Pública brasileira não ocorrendo nem em $1 \%$ das compras realizadas pela Administração Pública federal, o que se pressupõe, que se dará paulatinamente, com a inserção de medidas sustentáveis nos editais de licitação.

\section{Referências}

ARAÚJO, Edmir Netto de. Curso de Direito Administrativo. 6 ed. rev. e atual. São Paulo : Saraiva, 2014

BRASIL. Decreto n. 7.746, de 5 de junho de 2012. Regulamenta o art. 30 da Lei no 8.666, de 21 de junho de 1993, para estabelecer critérios, práticas e diretrizes para a promoção do desenvolvimento nacional sustentável nas contratações realizadas pela administração pública federal, e institui a Co- 
missão Interministerial de Sustentabilidade na Administração Pública - CISAP. Disponível em: http://www.planalto.gov.br/ccivil_03/_ato2011-2014/2012/decreto/d7746.htm. Acesso em 01 de outubro de 2015

Constituição (1988). Constituição da República Federativa do Brasil: promulgada em 5 de outubro de 1988. Disponível em: http:// www.planalto.gov.br/ccivil_03/constituicao/constitui\%C3\%A7ao.htm. Acesso em: 02 de outubro de $201 \overline{5}$.

Instrução Normativa SLTI/MPOG n. 01. Dispõe sobre os critérios de sustentabilidade ambiental na aquisição de bens, contratação de serviços ou obras pela Administração Pública Federal direta, autárquica e fundacional e dá outras providências. Disponível em: http:// cpsustentaveis.planejamento.gov.br/wp- content/uploads/2010/03/ Instru\%C3\%A7\%C3\%A3o-Normativa-01-10.pdf. Acesso em: 02 de outubro de 2015

Lei no 8.666, de 21 de junho de 1993. Regulamenta o art. 37, inciso XXI, da Constituição Federal, institui normas para licitações e contratos da Administração Pública e dá outras providências. Disponível em: http:// www.planalto.gov.br/ccivil 03/leis/l8666cons.htm. Acesso em: 01 de outubro de 2015

Lei n. 12.187, de 29 de dezembro de 2009. Institui a Política Nacional sobre Mudança do Clima - PNMC e dá outras providências. Disponível em: http://www.planalto.gov.br/ccivil_03/_ato2007-2010/2009/lei/ I12187.htm. Acesso em: 02 de outubro de $20 \overline{15}$

Medida Provisória n. 495, de 19 de julho de 2010. Altera as Leis nos 8.666, de 21 de junho de 1993, 8.958, de 20 de dezembro de 1994, e 10.973 , de 2 de dezembro de 2004 , e revoga o $\S 1$ do art. 2oda Lei no 11.273 , de 6 de fevereiro de 2006. Disponível em: https://www.planalto.gov.br/ccivil_03/ _Ato2007-2010/2010/Mpv/495.htm. Acesso em: 01 de outubro de 2015

Tribunal de Contas da União. Acórdão n. 1978/2009. Plenário. Relator: Marcos Bemquerer. Sessão de 2 de setembro de 2009. Disponível em: https://contas.tcu.gov.br/juris/SvlHighLight Acesso em: 10 de maio de 2015

CARVALHO FILHO, José dos Santos. Manual de Direito Administrativo. $28^{a}$ Ed. Revista e Atual. São Paulo: Atlas, 2015.

COMISSÃO MUNDIAL SOBRE MEIO AMBIENTE E DESENVOLVIMENTO. Nosso Futuro Comum. $2^{\mathrm{a}}$ Ed. Rio de Janeiro: Editora da Fundação Getúlio Vargas, 1991.

DI PIETRO, Maria Sylvia Zanella. Direito Administrativo. 24ª Ed. São Paulo, Atlas, 2011.

DIAS, Guilherme Vieira e TOSTES, José Glauco Ribeiro. Desenvolvimento sustentável: do ecodesenvolvimento ao capitalismo verde. Disponível em: 
http://www.socbrasileiradegeografia.com.br/revista_sbg/Artigos_arquivos/ GUILHERME_artigo_SBG.pdf Acesso em: 02 de outubro de 2015

FIGUEIREDO, Lúcia do Valle e FERRAZ, Sérgio. Dispensa e Inexigibilidade de Licitação, de acordo com a CF/1988 e as Leis 8666/93 e 8883/1994. São Paulo: Malheiros Editores, 1994

LAYRARGUES, Philippe Pomier. A cortina de fumaça: o discurso empresarial verde e a ideologia da racionalidade econômica. São Paulo: Annablume, 1998.

LEIS, Hector Ricardo. A Modernidade Insustentável: as criticas do ambientalismo à sociedade contemporânea, 3 ed. São Paulo : Annablume, 2014

JUSTEN FILHO. Marçal. Curso de Direito Administrativo. 10 ed. - rev., atual. e ampl., - São Paulo : Editora Revista dos Tribunais, 2014

$\neg$. Comentários à Lei de Licitações e Contratos Administrativos. 15 ed., São Paulo : Dialética, 2012

MINISTÉRIO DO PLANEJAMENTO, ORÇAMENTO E GESTÃO. Painel de Compras -. Disponível em: http://189.9.7.60/QvAJAXZfc/ opendoc.htm?document=Painel\%20de\%20Compras.qvw\&host=QVS\%40winuep82lprjmh\&anonymous=true Acesso em: 03 de outubro de 2015

MOTTA, Carlos Pinto Coelho. Eficácia nas licitações e contratos. Belo Horizonte, Editora Del Rey, 2005.

NIEBUHR, Joel de Menezes. Licitação pública e contrato administrativo. 2. ed. rev. e ampl. 1. reimpr. Belo Horizonte: Fórum, 2012.

ROSILHO, André. Licitação no Brasil. São Paulo: Malheiros Editores, 2013

SILVA, José Afonso da. Direito Ambiental Constitucional. 9a ed. atual. São Paulo: Malheiros Editores, 2011.

VIEIRA, André Luis. As contratações públicas sustentáveis na realidade brasileira. Disponível em: http://www.academia.edu/12121685/Contrata\% C3\%A7\%C3\%B5es_p\%C3\%BAblicas_sustent\%C3\%A1veis_na_realidade_brasileira Acesso em: 02 de outubro de 2015

\section{Notas}

${ }^{1}$ Graduada e Mestra em Direito pela Universidade Federal de Santa Catarina. Atua como professora de Graduação e Pós-Graduação em Direito Administrativo desde 2002. Autora de livros na área de Direito Público. Advogada.

${ }^{2}$ Podem ser considerados princípios gerais da Administração Pública os princípios da legalidade, impessoalidade, moralidade, publicidade e eficiência previstos no artigo 37, caput, da CRFB/88. 